\title{
Erratum to: Analysis of the Characteristics of an Electromechanical Starter in a Gas Turbine Plant
}

\author{
Yu. A. Makaricheve, *, Yu. V. Zubkov ${ }^{a}$, Yu. N. Ivannikov ${ }^{a}$, and I. V. Gulyaev ${ }^{b}$ \\ ${ }^{a}$ Samara State Technical University, Samara, 443100 Russia \\ ${ }^{b}$ Ogarev Mordovia State University, Saransk, 430005 Russia \\ *e-mail:journal-elektrotechnika@mail.ru \\ Submitted February 26, 2019; accepted for publication February 26, 2019
}

DOI: $10.3103 / \mathrm{S} 1068371220030165$

The indication of affiliation of the second and third authors should be "a".

The original article can be found online at

https://doi.org/10.3103/S1068371219070095 